\title{
Composted sewage sludge as an alternative substrate for forest seedlings production
}

\author{
Mônica Moreno Gabira (1), \\ Richardson Barbosa Gomes da \\ Silva ${ }^{(2)}$, \\ Fernanda Pacheco de Almeida \\ Prado Bortolheiro ${ }^{(2)}$, \\ Caroline de Moura D'Andrea \\ Mateus ${ }^{(2)}$, \\ Roberto Lyra Villas Boas ${ }^{(2)}$, \\ Sergio Rossi ${ }^{(3-4)}$, \\ Miguel Montoro Girona ${ }^{(5-6)}$, \\ Magali Ribeiro da Silva ${ }^{(2)}$
}

The production of forest seedlings with adequate morphological and physiological characteristics is essential for the success of plantations. Substrates and irrigation are the major factors determining seedlings' growth. Substrates made of urban and agricultural residues are a sustainable alternative to peatbased substrates. In this study, we evaluated how composted sewage sludge substrates affect the growth and gas exchange in seedlings of Cedrela fissilis Vell. Seedlings were produced under daily irrigation depths of 6,9 , and 12 $\mathrm{mm}$, and on different substrates. The substrates were based on sewage sludge composted with Eucalyptus bark or sugarcane bagasse, and a commercial substrate based on peat, involving a double factorial design with 12 treatments ( 3 irrigation depths $\times 3$ substrates). Both physical and chemical characteristics of substrates were analyzed, and morphological traits and gas exchanges of seedlings were measured. Sewage sludge-based substrates presented different characteristics according to the material it was mixed. Eucalyptus bark provided higher bulk density $\left(0.19 \mathrm{~g} \mathrm{~cm}^{-3}\right)$ and lower total porosity (75\%) to the substrate, while sugarcane bagasse increased macroporosity up to $60 \%$. Seedlings produced in sewage sludge-based substrates presented a height up to $17.8 \mathrm{~cm}$ and stem diameters of between 8.39-10.29 mm. Higher shoot and root dry mass was obtained in sewage sludge-based substrates with irrigation depth of $9 \mathrm{~mm}$, which were 3.71 and $2.01 \mathrm{~g}$, respectively. Photosynthetic carbon assimilation varied between 2.26 and $3.23 \mu \mathrm{mol} \mathrm{CO}_{2} \mathrm{~m}^{-2} \mathrm{~s}^{-1}$, and water use efficiency varied from 2.058 to $3.395 \mu \mathrm{mol} \mathrm{CO}_{2}\left(\mathrm{~mol} \mathrm{H}_{2} \mathrm{O}\right)^{-1}$, with the highest values being obtained in seedlings produced in sewage sludge-based substrates with irrigation depth of $6 \mathrm{~mm}$. Our results demonstrate that sewage sludgebased substrates are an efficient alternative to commercial peat-based substrates for seedling production.

Keywords: Agricultural Residues, Cedrela fissilis, Forest Nursery, Gas Exchange, Irrigation, Plant Growth, Silviculture, Solid Wastes

\section{Introduction}

Production and use of tree seedlings are important components of forest management. Proper understanding of the relationship between seedling quality and field establishment is the key for new plantations and natural regeneration (Dumroese et al. 2016, Girona et al. 2018). Among the factors affecting seedling growth and quality, the more important ones are cultural practices like irrigation, nutrition, container size, and type, as well as substrate (Kormanek et al. 2020, Madrid-Aispuro et al. 2020). Hardened seedlings, with adequate morphological and physiological attributes, are more likely to reach their greatest growth potential soon after field planting, guaranteeing their survival in adverse environmental conditions (Grossnickle \& MacDonald 2018).

Among the substrates available for seedling production, vermiculite combined with peat has been used for a long time in forest nurseries (Raviv 2013). However, its availability is limited, it can be expensive if imported, and harvesting peat causes ecological impacts (Madrid-Aispuro et al. 2020). Several studies have shown that it is possible to obtain substrates made of residues with good physical characteristics, which provides tree seedlings with well-aggregated and quality root systems to be transplanted in the field (Fermino et al. 2018, Fornes \& Belda 2019, Gabira et al. 2020a, Sá et al. 2020). In recent years, sewage sludge has also been evaluated to be used as a potential substrate (Kratz et al. 2017, Lopes et al. 2018). Because of its origin, sewage sludge presents a variability in composition, preventing its use at a commercial level based on the actual knowledge on the performance of the product (Nascimento et al. 2020). Nevertheless, the use of sewage sludge reduces the acquisition of commercial substrates and chemical fertilizers, representing a sustainable alternative to landfill disposal (Manca et al. 2020). Research using sewage sludge on seedling production focuses mainly on substrate characteristics and plant morphological responses, but the relationships between these substrates and other production factors on plant growth and gas exchange are still lacking.

Sugarcane and eucalypt industries are very remarkable in Brazil, producing large 
amounts of waste. Eucalyptus is the most important source of biomass for paper pulp and wood industries, which generate large amounts of waste since the bark is not used as a valuable product (Chemetova et al. 2018). In 2018, the Brazilian forestry sector produced $52 \mathrm{Mt}$ of solid waste, 36.9 Mt of which was composed of barks, branches, and leaves (IBA 2019). Another agro-industrial residue, sugarcane bagasse, is the waste of the sugar and biofuel industries. It represents $30-33 \%$ of the weight of sugarcane, and it is mostly used for energy, but remains an important environmental problem (Sahu 2018, Braga et al. 2019). The use of these residues as substrates for forest seedlings is an important alternative, reducing environmental impact and aggregating value for these products (Chemetova et al. 2018, Lopes et al. 2018).

Cedrela fissilis Vell. is a native species from South America. Its wood is known for the high quality, rich extractive compounds, and natural durability, making it a promising species for commercial plantations (Georgin et al. 2019). In addition to its economic importance, it is considered among Brazilian endangered species (Barstow 2018). Both aspects raise the need for developing studies on its distribution, silvicultural treatments, breeding, and genetic selection (Navroski et al. 2016), as well as factors influencing the seedlings' production and establishment after planting.

The aim of this study was to evaluate how substrates based on composted sewage sludge affect the growth and gas exchange of Cedrela fissilis seedlings under different irrigation depths. Our hypotheses are that: (i) substrates based on sewage sludge mixed with sugarcane bagasse or eucalyptus bark enable growth and biomass accumulation similar to the commercial substrate; and (ii) seedlings in a substrate with lower water holding capacity need higher irrigation depths to maintain growth and photosynthetic activity.

\section{Material and methods}

Experimental design and plant material The experiment was conducted between November 2016 and April 2017 in a suspended, sectored nursery in Botucatu (São Paulo State), Brazil ( $22^{\circ} 51^{\prime} \mathrm{S}, 48^{\circ} 25^{\prime} \mathrm{W}$; 780 $\mathrm{m}$ a.s.l.). The climate of the region is tropical, with hot and rainy summers and dry winters. The mean annual temperature is $19.1^{\circ} \mathrm{C}$, and annual precipitation is $1324 \mathrm{~mm}$. The region has the typical vegetation of a seasonal semi-deciduous forest under the Tropical Atlantic Forest biome.

C. fissilis seedlings were produced from seeds collected from mother trees in Botucatu and grown in polyethylene tubes ( 92 $\mathrm{cm}^{3}$ volume) containing different substrates. Two seeds per tube were sowed. The tubes were placed in polypropylene trays, which were kept in a greenhouse at $50 \%$ full solar radiation and irrigated with $200 \mathrm{~L} \mathrm{~h}^{-1}$ flow micro-sprinklers, automati- cally activated for 20 seconds, every 30 minutes from 9 AM to 4 PM for 30 days. After germination, one plant was maintained in each tube. The experiment was carried out in a completely randomized design with a $3 \times 3$ factorial scheme (three substrates $\times$ three irrigation depths). Each treatment consisted of four replications of 12 seedlings, totaling 48 seedlings per treatment (overall, 432 seedlings).

\section{Treatments}

The substrates were produced from domestic sewage sludge resulting from treatment in Up-flow Anaerobic Sludge Blanket (UASB) reactor system and complementary treatment with conventional activated sewage sludge. The sludge was composted with structuring residues (sugar cane bagasse or Eucalyptus sp. bark) for 90 days, at a ratio of 1:3 v:v. Sugarcane bagasse and Eucalyptus bark are industrial residues obtained from the sugar and paper industries. In addition to the social and environmental issues, these residuals have a fibrous structure with the potential to improve the physical characteristics of sewage sludge. Mixtures were arranged into piles in a 150micron plastic-covered composting patio supported by metal frame with open sides. Piles were turned by a composting machine twice a week for the entire composting period.

The resultant materials from the sewage sludge composting process were used as substrates. These consisted of sewage sludge composted with sugarcane bagasse $(1: 3 \mathrm{v}: \mathrm{V}-\mathrm{SCB}$ ) and sewage sludge composted with Eucalyptus bark (1:3 v:v - SEB). As a control, we used a commercial substrate composed of Sphagnum peat, vermiculite, and roasted rice husk (2:1:1 v:v:v). Domestic sludge lacks in heavy metals ( $\mathrm{Na}$ scimento et al. 2020), and no pathogenic microorganism was detected in the material used as substrate after the composting process.

The seedlings trays were placed into suspended beds, covered with light-diffusing plastic in an area under full sunlight in the nursery to start the application of different irrigation depths. In each tray, the density was 120 tubes $\mathrm{m}^{-2}$. Water management involved applying three daily irrigation depths $(6,9$, and $12 \mathrm{~mm})$ in two installments, both at 10 AM and 2 PM. Irrigation depths were defined from studies by Silva \& Silva (2015).

All treatments received the same amount of growth fertilizer during the application of irrigation depths. Seedlings received 3 $\mathrm{mm}$ of a nutrient solution via fertigation by the micro-sprinkler system twice a week. The macronutrient solution consisted of purified mono ammonium phosphate, magnesium sulfate, potassium chloride, calcium nitrate, and urea fertilizers at the concentrations of $488,155.4,328.1,312$, 72.2 , and $98.8 \mathrm{mg} \mathrm{L}^{-1}$ of $\mathrm{N}, \mathrm{P}, \mathrm{K}, \mathrm{Ca}, \mathrm{Mg}$ and $\mathrm{S}$, respectively. The micronutrient solution consisted of boric acid, sodium, molybdate and manganese sulfates, zinc, copper, and iron at the concentrations of 4.6, 3.9, 1.2, $0.6,0.3$ and $2.5 \mathrm{mg} \mathrm{L}^{-1}$ of B, Mn, Zn, Cu, Mo, and $\mathrm{Fe}$, respectively. At 120 days after sowing, seedlings started to receive a nutrient solution composed of potassium chloride at a concentration of $750 \mathrm{mg} \mathrm{L}^{-1} \mathrm{~K}$. We carried out the experiment until at least one of the treatments presented seedlings that were suitable for field planting, i.e., with a well-developed root across the whole substrate.

\section{Measurements and data collection}

To determine the substrates' properties, we measured total porosity, macroporosity, microporosity, and water holding capacity of each substrate according to the methodology described by Guerrini \& Trigueiro (2004). This methodology consisted in filling polyethylene tubes with the substrates, letting them under the water for $24 \mathrm{~h}$, weighting, let them drain for $1 \mathrm{~h}$, and then weighting again. After, substrates were dried in an oven for $24 \mathrm{~h}$ and then weighed again. Physical attributes were calculated using these data. Chemical characterization of available nutrients was performed according to Sonneveld (1988), which assessed the concentrations of $\mathrm{N}, \mathrm{P}$, $\mathrm{K}, \mathrm{Ca}, \mathrm{Mg}, \mathrm{S}, \mathrm{Na}, \mathrm{B}, \mathrm{Cu}, \mathrm{Fe}, \mathrm{Mn}, \mathrm{Zn}$, as well as $\mathrm{pH}$ and electrical conductivity (EC) of the substrates. It consists of aqueous extraction in a proportion of 1:1.5 (v:v), stirred for 30 minutes, and then filtered through medium filtering paper (Nalgon 3550).

To evaluate seedlings' growth at the end of the experiment (151 days after sowing), we measured height, stem diameter, shoot, root, and total dry mass, and Dickson quality index (DQI). To measure height $(\mathrm{cm})$, we used a millimeter ruler, measuring from the stem to the apical bud. Stem diameter ( $\mathrm{mm}$ ) was measured using a digital caliper positioned horizontally on the seedling stem. Shoot and root dry mass (g) was obtained by sectioning the seedling at stem height. The root systems were washed in running water to remove the substrate and placed in paper bags in a drying oven at $70{ }^{\circ} \mathrm{C}$ until reaching a constant mass. Total dry mass and Dickson quality index (DQI) were determined by the combination of the abovementioned growth variables.

The gas exchange was evaluated with an infrared gas analyzer IRGA, model LI $6400^{\circledR}$ (LI-COR, Lincoln, NE, USA). Gases were evaluated at the end of the experiment, between $9 \mathrm{AM}$ and $11 \mathrm{AM}$, during a sunny day. The $\mathrm{CO}_{2}$ concentration used as reference was the one from the environment, which varied between 380 and $400 \mu \mathrm{mol}$ $\mathrm{CO}_{2} \mathrm{~mol}^{-1}$. Carbon assimilation $(\mathrm{A}, \mu \mathrm{mol} \mathrm{CO}$

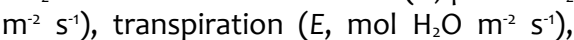
stomatal conductance $\left(\mathrm{g}_{\mathrm{s}}, \mathrm{mol} \mathrm{H}_{2} \mathrm{O} \mathrm{m}^{-2} \mathrm{~s}^{-1}\right)$, and intracellular carbon concentration $\left(C_{i}\right.$, $\mu \mathrm{mol} \mathrm{CO}_{2}$ mol air-1) were recorded. From this data, we calculated the water use efficiency [WUE, $\mu \mathrm{mol} \mathrm{CO}_{2}\left(\mathrm{~mol} \mathrm{H}_{2} \mathrm{O}\right)^{-1}$ ], determined by the $A / E$ ratio, and the carboxyla- 
tion efficiency, determined by the $A / C_{i}$ ratio.

\section{Statistical analysis}

Data were submitted to the Shapiro-Wilk test to verify the normality of the variables and to Bartlett test to verify homogeneity of variances; we did not perform data transformation for statistical analysis. Analyses of Variance (ANOVA) was performed for physical and chemical characteristics of the substrates, and for growth and gas exchange data. Tukey test was applied for multiple comparisons. We used the R software to perform analysis ( $R$ Core Team 2020).

\section{Results}

\section{Physical and chemical characteristics of} substrates

The physical characteristics varied greatly according to substrate composition (Tab. 1). Compared with the other substrates, SCB increased macroporosity up to $60 \%$; water holding capacity decreased to 14.0 $\mathrm{mL} 55 \mathrm{~cm}^{-3}$, the lowest value among the substrates used in this experiment. The characteristics of SCB differed mostly from $\mathrm{CS}$, which presented the highest microporosity and water holding capacity, 59.0\%

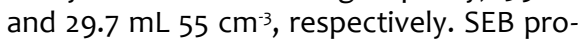
vided intermediate values of macroporosity (32.3\%), microporosity (43.0\%), and water holding capacity $(22.0 \%)$, as well as the highest bulk density $\left(0.19 \mathrm{~g} \mathrm{~cm}^{-3}\right)$ and the lowest total porosity (75.0\%).

The substrates with sewage sludge had more acidic pH (5.92 for SEB and 4.93 for $\mathrm{SCB}$ ) and superior electrical conductivity (3.45 for SEB and 2.93 for SCB) compared to the commercial substrate $(6.30 \mathrm{pH}$ and $\left.0.89 \mathrm{dS} \mathrm{m}^{-1}\right)$. Overall, the macronutrient and micronutrient contents of sewage sludge substrates were higher than those of the commercial substrate, especially in $\mathrm{N}, \mathrm{Ca}, \mathrm{Mg}, \mathrm{S}$, and $\mathrm{Mn}$. CS presented higher levels of $\mathrm{P}$ and $\mathrm{Cu}$ and $\mathrm{K}, \mathrm{Fe}$, and $\mathrm{Mn}$ compared to SEB.

\section{Seedling growth}

Seedling growth was influenced by irrigation depths and substrates, with a significant interaction between the factors for all morphological variables $(p<0.05)$. Seedlings produced in SEB presented superior height when compared to the other substrates in all irrigation depths - 16.7, 16.3, and $17.8 \mathrm{~cm}$ for seedlings produced in 6,9 , and $12 \mathrm{~mm}$, respectively (Fig. 1a). The lowest height value was $14.7 \mathrm{~cm}$, observed in seedlings produced in SCB with $6 \mathrm{~mm}$ irrigation depth. Stem diameter presented little variation (8.39-10.29 mm). We observed the lowest stem diameter in seedlings produced in SEB with $6 \mathrm{~mm}$ irrigation depth, while the highest value was observed in seedlings produced in CS with $9 \mathrm{~mm}$ irrigation depth (Fig. 1b). Seedlings in SCB presented the lowest stem diameter when produced with 9 and $12 \mathrm{~mm}$ irrigation

Tab. 1 - Macroporosity, microporosity, total porosity, water holding capacity (WHC), and bulk density of the substrates used to produce Cedrela fissilis seedlings. Averages followed by the same letter in the row do not differ $(p>0.05)$ by Tukey test. (CS): Commercial substrate of Sphagnum peat, vermiculite and rice husk (2:1:1 v:v:v); (SCB): sewage sludge + sugar cane bagasse (1:3 v:v); (SEB): sewage sludge + Eucalyptus bark $(1: 3 \mathrm{v}: \mathrm{v})$.

\begin{tabular}{lccc}
\hline \multirow{2}{*}{ Physical characteristics } & \multicolumn{3}{c}{ Substrate } \\
\cline { 2 - 4 } & CS & SCB & SEB \\
\hline Macroporosity (\%) & $24.0^{\mathrm{c}}$ & $60.0^{\mathrm{a}}$ & $32.0^{\mathrm{b}}$ \\
\hline Microporosity (\%) & $59.0^{\mathrm{a}}$ & $27.0^{\mathrm{c}}$ & $43.0^{\mathrm{b}}$ \\
\hline Total porosity (\%) & $83.0^{\mathrm{b}}$ & $87.0^{\mathrm{a}}$ & $75.0^{\mathrm{c}}$ \\
\hline WHC (mL 55 cm $\mathrm{cm}^{-3}$ & $29.7^{\mathrm{a}}$ & $14.0^{\mathrm{c}}$ & $22.2^{\mathrm{b}}$ \\
\hline Bulk density $\left(\mathrm{g} \mathrm{cm}^{-3}\right)$ & $0.1^{\mathrm{b}}$ & $0.1^{\mathrm{b}}$ & $0.2^{\mathrm{a}}$ \\
\hline
\end{tabular}

depth ( 9.49 and $9.25 \mathrm{~mm}$, respectively).

We observed higher shoot and root dry mass in seedlings produced in SEB with 9 $\mathrm{mm}$, which were 3.71 and $2.01 \mathrm{~g}$, respectively (Fig. 1c, d). For shoot dry mass, seedlings produced in SCB presented the lowest values in all irrigation depths - 2.28 , 2.98 , and $2.68 \mathrm{~g}$ for seedlings produced in 6,9 , and $12 \mathrm{~mm}$, respectively. For shoot dry mass, we observed the lowest value in seedlings produced in CS with $6 \mathrm{~mm}$ irrigation depth. Total dry mass, as a result of the shoot and root dry mass, also had seedlings produced in SEB with $9 \mathrm{~mm}$ as the higher value $(5.71 \mathrm{~g})$ and the lowest value in seedlings produced in CS with 6 $\mathrm{mm}$ (3.82 g) (Fig. 1e). Dickson quality index indicates that SEB and CS under $9 \mathrm{~mm}$ irrigation depths provided better growth and mass accumulation of seedlings; in these
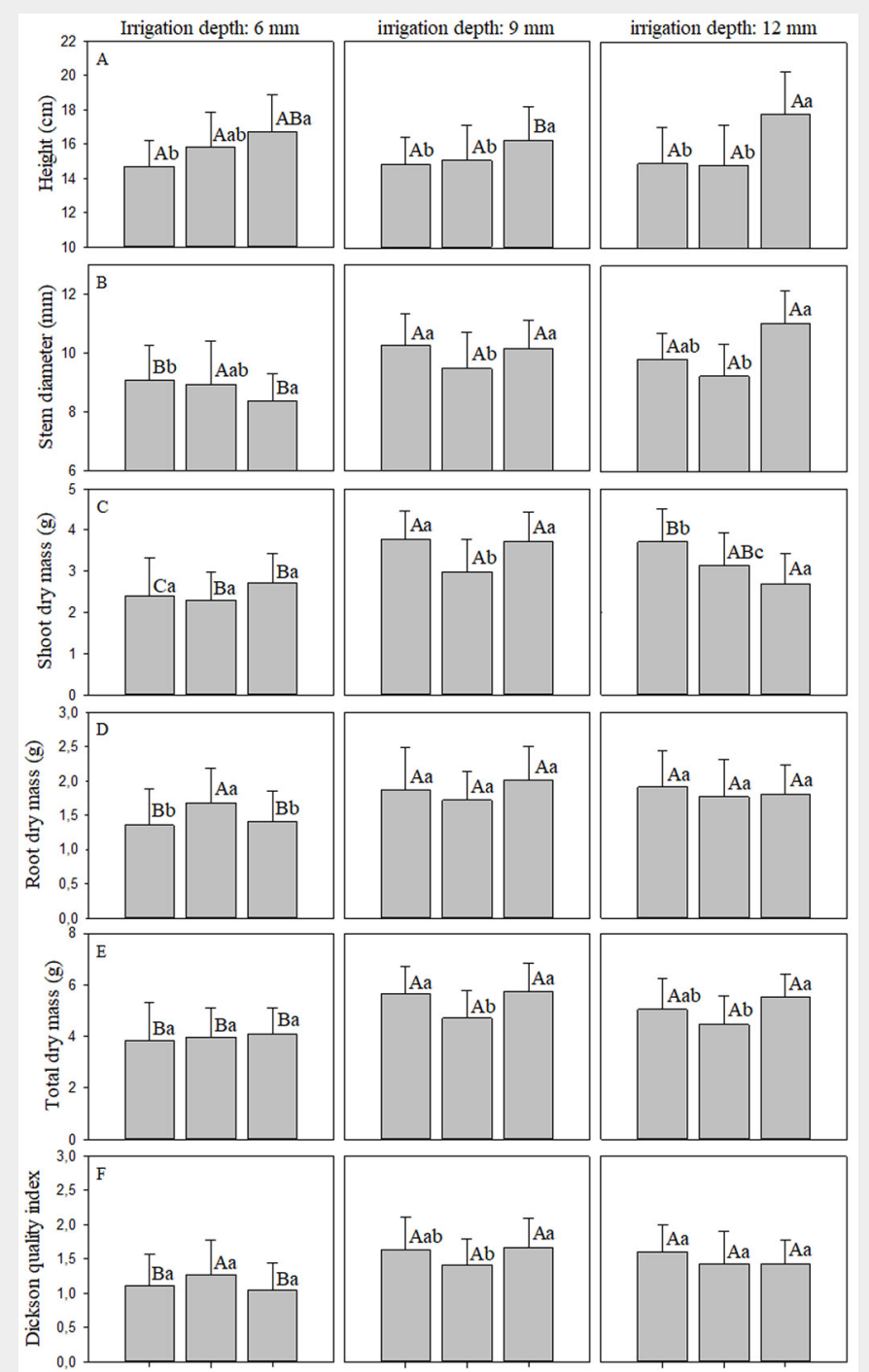

SC SCB SEB
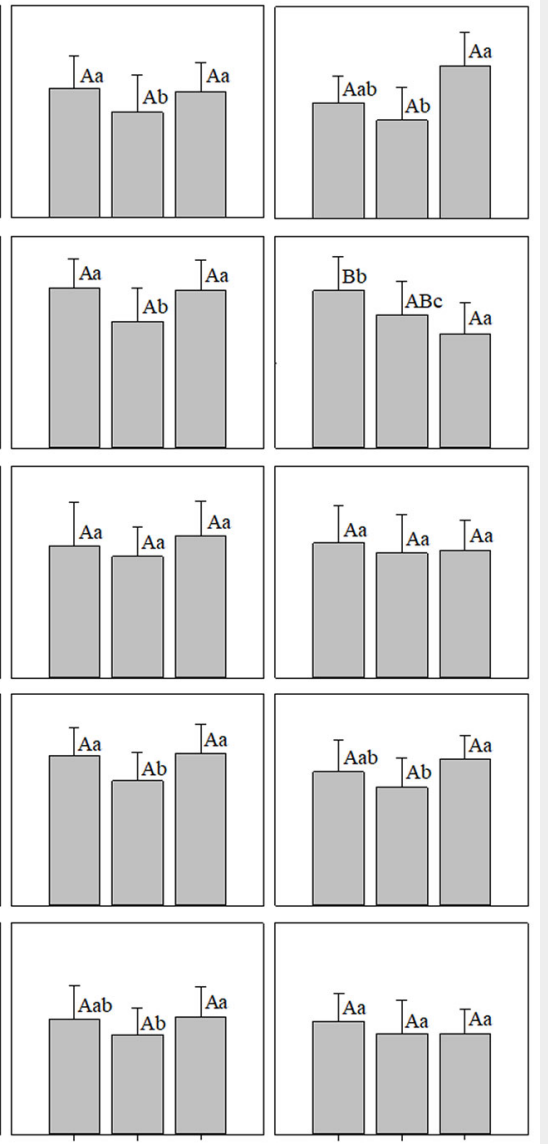

SC SCB SEB
Fig. 1 - Height, stem diameter, shoot dry mass, root dry mass, total dry mass, and Dickson quality index of Cedrela fissilis seedlings at 151 days after sowing. (CS): Commercial substrate composed of Sphagnum peat, vermiculite, and rice husk (2:1:1 v:v:v); (SCB): sewage sludge + sugar cane bagasse (1:3 v:v); (SEB): sewage sludge + Eucalyptus bark $(1: 3 \mathrm{v}: \mathrm{v})$. 


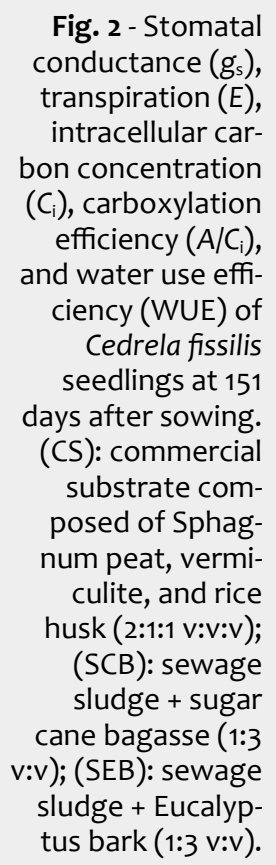

Fig. 2 - Stomatal conductance $\left(g_{s}\right)$, transpiration $(E)$, intracellular carbon concentration $\left(C_{i}\right)$, carboxylation efficiency $\left(A / C_{i}\right)$, and water use efficiency (WUE) of Cedrela fissilis seedlings at 151 days after sowing. (CS): commercial substrate composed of Sphagnum peat, vermiculite, and rice husk (2:1:1 v:v:v); (SCB): sewage sludge + sugar cane bagasse (1:3 v:v); (SEB): sewage sludge + Eucalyptus bark (1:3 v:v).
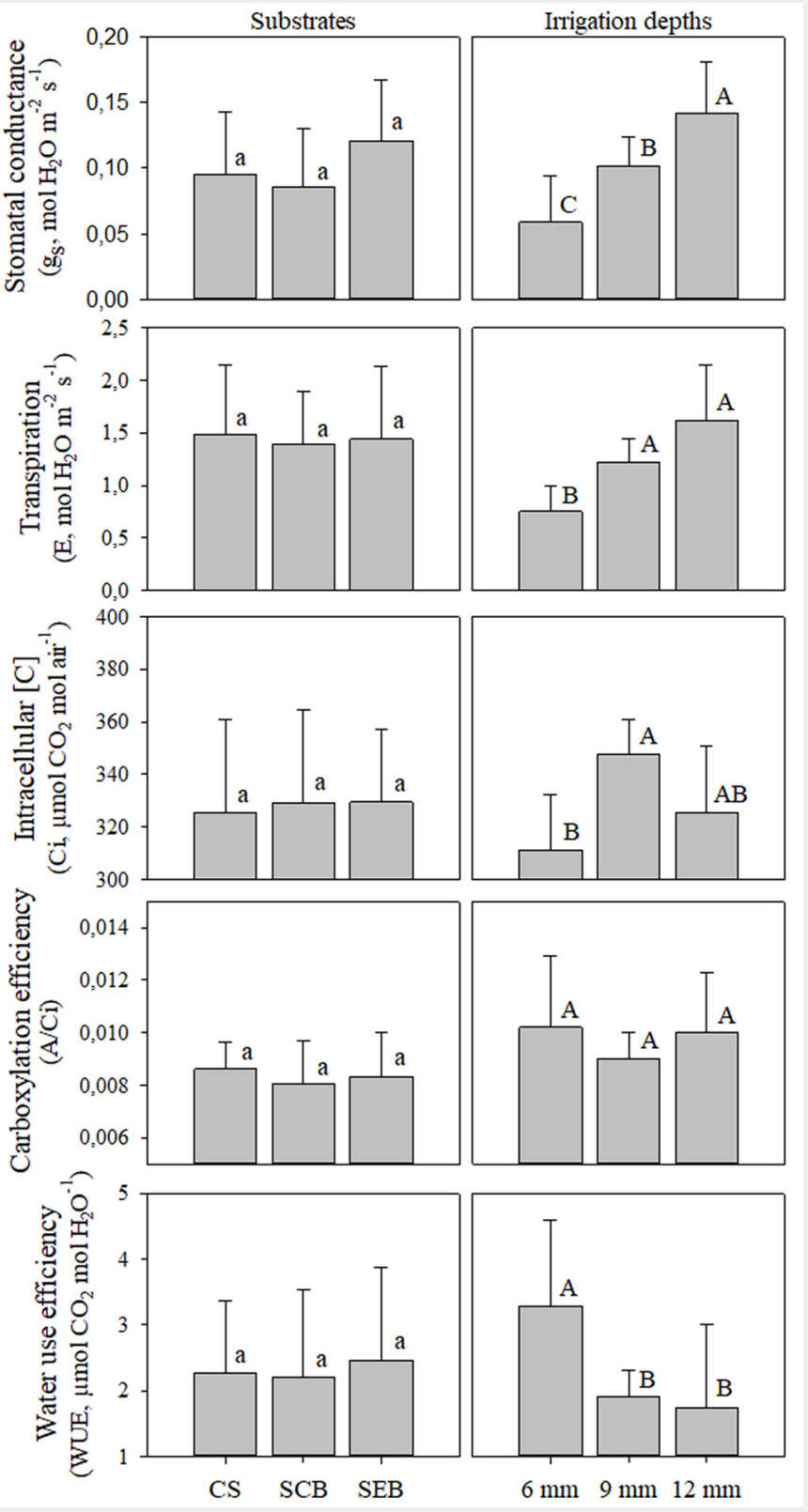

treatments. Seedlings DQI were 1.70 and 1.68, respectively (Fig. 1f).

\section{Gas exchange}

We observed an increase in photosynthetic carbon assimilation (A) for seedlings produced in CS associated with the increase in irrigation depth $-2.26,2.89$, and
$3.23 \mu \mathrm{mol} \mathrm{CO}_{2} \mathrm{~m}^{-2} \mathrm{~s}^{-1}$ for 6,9 , and $12 \mathrm{~mm}$ (Fig. 2). For seedlings in SEB, a decrease in $A$ was associated with the increase in irrigation depth, with values varying from 3.23 to $2.28 \mu \mathrm{mol} \mathrm{CO}_{2} \mathrm{~m}^{-2} \mathrm{~s}^{-1}$ in seedlings produced under 6 and $12 \mathrm{~mm}$. Seedlings in SCB presented intermediate values of $A$, which varied between 2.45 and $2.75 \mathrm{CO}_{2} \mathrm{~m}^{-2} \mathrm{~s}^{-1}$. A was the only photosynthetic variable that presented statistical interaction between both substrates and irrigation depths.

There was a similar tendency among seedlings produced in all substrates when regarding these variables, which did not present differences among substrates. Analyzing differences in irrigation depths, the higher value for $g_{s}$ was obtained in seedlings produced with $12 \mathrm{~mm}$ irrigation depth ( $0.173 \mathrm{~mol} \mathrm{H}_{2} \mathrm{O} \mathrm{m}^{-2} \mathrm{~s}^{-1}$ ), and the lower value was obtained in seedlings produced with 6 $\mathrm{mm}$ irrigation depth $\left(0.048 \mathrm{~mol} \mathrm{H}_{2} \mathrm{O} \mathrm{m}^{-2} \mathrm{~s}^{-1}-\right.$ Fig. 2). Transpiration varied from 0.804 to $1.88 \mathrm{~mol} \mathrm{H}_{2} \mathrm{O} \mathrm{m}^{-2} \mathrm{~s}^{-1}$ in seedlings produced with $6 \mathrm{~mm}$ and with $12 \mathrm{~mm}$ irrigation depth, respectively (Fig. 2).

There was little variation in the intracellular $C_{i}$ (Fig. 2) and $C / C_{i}$, indicating that variations in substrate characteristics and irrigation depths did not sufficiently alter these variables. With increased irrigation depths, WUE reduced significantly, indicating that increased irrigation depths promote greater water loss by plants to produce the same amount of biomass. The highest WUE was obtained in seedlings produced with 6 $\mathrm{mm}$ irrigation depth $\left[1.94 \mu \mathrm{mol} \mathrm{CO}_{2}\right.$ (mol $\left.\left.\mathrm{H}_{2} \mathrm{O}\right)^{-1}\right]$, and the lowest WUE was obtained in seedlings produced with $12 \mathrm{~mm}$ irrigation depth $\left[0.90 \mu \mathrm{mol} \mathrm{CO}_{2}\left(\mathrm{~mol} \mathrm{H} \mathrm{H}_{2} \mathrm{O}\right)^{-1}\right]$. For stomatal conductance $\left(g_{s}\right)$, transpiration $(E)$, intracellular $C\left(C_{i}\right)$, carboxylation efficiency $\left(C / C_{i}\right)$, and water use efficiency (WUE), there was not interaction between factors, and differences were significant only for irrigation depths (Fig. 3).

\section{Discussion}

\section{Physical and chemical characteristics of} substrates

The close relationship between substrate porosity and the availability of air and water for plant root system growth highlights the importance of these characteristic, associated with water management, for forest seedling production (Pascual et al. 2018). The addition of Eucalyptus bark to sewage sludge increased microporosity, and the addition of sugarcane bagasse increased macroporosity (Tab. 1). Organic compounds, such as sewage sludge, have high density and, consequently, low total porosity (Raviv 2013), but we observed that the addition of structuring materials

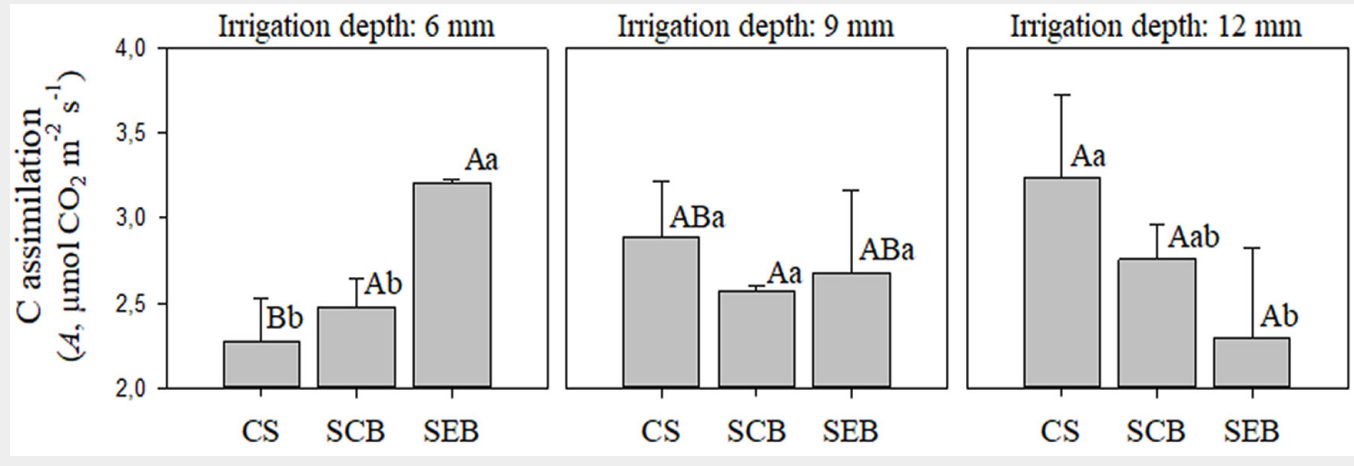

Fig. 3 - Carbon assimilation (A) of Cedrella fissilis seedlings at 151 days after sowing. (CS): commercial substrate composed of Sphagnum peat, vermiculite, and rice husk; (SCB): sewage sludge + sugar cane bagasse (1:3 v:v); (SEB): sewage sludge + Eucalyptus bark (1:3 v:v). 
into the composting process made these materials suitable for seedling production, as displayed in Fig. 1, Fig. 2, and Fig. 3.

In our experiment, substrates with different characteristics were obtained as a function of the constituent materials. The appearance of the particles that compose them, such as size and shape, is one of the main factors that directly affect the arrangement of mixtures (Fermino et al. 2018). The water holding capacity of a substrate is the result of these characteristics and is important for establishing water management in seedling production, as it determines water drainage after irrigation. Among the substrates used in this study, only SBC presented a reduced value for this characteristic, probably due to the fibrous character of sugarcane bagasse. The adequate physical characteristics of substrates to produce forest seedlings can vary according to several factors such as the species needs, type of packaging, propagation form, and management adopted in the nursery must be considered (Fornes \& Belda 2019, Gabira et al. 2020b).

The chemical characteristics of substrates were also influenced by the materials of which they were composed. The substrate SEB presented high levels of $\mathrm{Ca}, \mathrm{Mg}, \mathrm{Na}, \mathrm{K}$, $\mathrm{B}$, and Fe (Tab. 2), which can be explained by the high concentration of these nutrients in Eucalyptus bark (Salvador et al. 2016). High $\mathrm{N}$ contents, observed mainly on $\mathrm{SCB}$, are important to regulate other nutrients uptake and interactions necessary for plants growth (Hu \& Chu 2020). Adding sewage sludge to the substrates enhanced nutrients and organic matters content in SEB and SCB according to previous studies (Guerrini \& Trigueiro 2004, De Abreu et al. 2017, Gabira et al. 2020a). The higher $P$ content observed in SC $\left(33.33 \mathrm{mg} \mathrm{L}^{-1}\right)$ is due to the addition of simple superphosphate $\left(\mathrm{P}_{2} \mathrm{O}_{5}\right)$ by the substrate manufacturer.

The $\mathrm{pH}$ of organic substrates used for seedling production should be around neutrality, between 5.0 and 6.0, for better availability of nutrients (Taiz et al. 2014). Thus, all the substrates used in this experiment match the recommendations. Substrate $\mathrm{pH}$ directly affects the mobility and availability of ions and, when outside the indicated range, nutrient deficiency or toxicity may occur (Pascual et al. 2018). The electrical conductivity (EC) results were similar to those obtained by Guerrini \& Trigueiro (2004) for substrates with different proportions of sewage sludge. EC is related to the total amount of soluble salts in the saturated extract of the substrates; high EC values are expected in organic composts and can affect root growth (Raviv 2013). However, values outside this standard may not impair the growth of seedlings of certain species, as observed in this study with C. fissilis.

\section{Seedling growth}

Studies conducted in nurseries are based on morphological or physiological variables

Tab. 2 - Nutrient concentration (N, P, K, Ca, Mg, S, Na, B, Cu, Fe, Mn, Zn), pH and electrical conductivity of the substrates used to produce seminal seedlings of Cedrela fissilis. Averages followed by the same letter in the row do not differ $(p>0.05)$ by Tukey test. (CS): Commercial substrate of Sphagnum peat, vermiculite, and rice husk (2:1:1 v:v:v); (SCB): sewage sludge + sugar cane bagasse (1:3 v:v); (SEB): sewage sludge + Eucalyptus bark (1:3 v:v).

\begin{tabular}{|c|c|c|c|}
\hline \multirow{2}{*}{ Nutrients } & \multicolumn{3}{|c|}{ Substrates } \\
\hline & CS & SCB & SEB \\
\hline$N\left(m g ~ L^{-1}\right)$ & $0.66^{c}$ & $2.53^{a}$ & $1.84^{b}$ \\
\hline$P\left(\mathrm{mg} \mathrm{L}^{-1}\right)$ & $33.33^{\mathrm{a}}$ & $1.33^{b}$ & $1.33^{b}$ \\
\hline $\mathrm{K}\left(\mathrm{mg} \mathrm{L^{-1 }}\right)$ & $93.07^{\mathrm{b}}$ & $55.73^{c}$ & $159.07^{a}$ \\
\hline $\mathrm{Ca}\left(\mathrm{mg} \mathrm{L}^{-1}\right)$ & $23.67^{c}$ & $386.67^{b}$ & $613.33^{a}$ \\
\hline$M g\left(m g L^{-1}\right)$ & $49.00^{c}$ & $98.00^{\mathrm{b}}$ & $138.67^{a}$ \\
\hline $\mathrm{S}\left(\mathrm{mg} \mathrm{L}^{-1}\right)$ & $146.67^{b}$ & $560.00^{a}$ & $580.00^{a}$ \\
\hline $\mathrm{Na}\left(\mathrm{mg} \mathrm{L}^{-1}\right)$ & $24.56^{c}$ & $34.90^{\mathrm{b}}$ & $50.23^{a}$ \\
\hline $\mathrm{B}\left(\mathrm{mg} \mathrm{L}^{-1}\right)$ & $0.07^{\mathrm{b}}$ & $0.06^{\mathrm{b}}$ & $0.15^{a}$ \\
\hline $\mathrm{Cu}\left(\mathrm{mg} \mathrm{L}^{-1}\right)$ & $0.18^{a}$ & $0.10^{\mathrm{b}}$ & $0.11^{b}$ \\
\hline $\mathrm{Fe}\left(\mathrm{mg} \mathrm{L}^{-1}\right)$ & $1.33^{b}$ & $0.90^{c}$ & $2.47^{a}$ \\
\hline $\operatorname{Mn}\left(\mathrm{mg} \mathrm{L}^{-1}\right)$ & $0.51^{c}$ & $4.21^{b}$ & $6.07^{a}$ \\
\hline $\mathrm{Zn}\left(\mathrm{mg} \mathrm{L}^{-1}\right)$ & $0.69^{b}$ & $2.36^{a}$ & $0.44^{c}$ \\
\hline $\mathrm{pH}$ & $6.30^{a}$ & $4.93^{c}$ & $5.92^{b}$ \\
\hline $\mathrm{EC}\left(\mathrm{dS} \mathrm{m}^{-1}\right)$ & $0.89^{b}$ & $2.93^{a}$ & $3.45^{\mathrm{a}}$ \\
\hline
\end{tabular}

to determine seedling quality, however, it is important to relate seedlings characteristics to its survival after planting in the field (Grossnickle \& MacDonald 2018, Stuepp et al. 2020). The variables most used to determine forest seedlings' quality are height and stem diameter because the measurement is simple, fast, and non-destructive (Ivetić et al. 2016). The correlation with Dickson Quality Index also shows height and stem diameter as important indicators of seedling quality (Madrid-Aispuro et al. 2020). In this study, we obtained satisfactory values of these variables for all treatments, especially for seedlings produced in SEB.

Bortolini et al. (2017) recorded a maximum height of $22.2 \mathrm{~cm}$ in seedlings growing in substrates with sewage sludge 90 days after sowing. This result agrees with those obtained in our study $(23.0 \mathrm{~cm}$ in seedlings produced in SEB under $12 \mathrm{~mm}$ irrigation depth). Taller plants have an advantage in areas with vegetation competing for light; however, tall seedlings can have a higher sensitivity to wind and rain when growth is not accompanied by an increase in stem diameter (Grossnickle \& MacDonald 2018). Also Bueno et al. (2020) produced taller plants under higher irrigation depths. However, we observed that seedling height depended mainly on substrate characteristics, which was not evaluated by the authors.

Stem diameter was also influenced by substrates, although all the substrates allowed the growth of seedlings with an adequate diameter for outplanting, similar to those obtained by Navroski et al. (2016). Stem diameter is considered the best morphological attribute to forecast field growth, especially because it correlates with seedling weight and root system size (Stuepp et al. 2020). Ivetić et al. (2016) highlight that this morphological characteristic well correlates with initial growth in the field, although it is unable to predict seedlings' survival.

Regardless of irrigation depths, SEB provided seedlings with the largest amount of dry mass, although seedlings produced using $6 \mathrm{~mm}$ irrigation depth presented lower values than seedlings produced in SCB. Other studies using sugarcane bagasse and sewage sludge as substrate obtained better morphological characteristics of Eucalyptus and Peltophorum dubium seedlings growing under adequate irrigation depths (Gabira et al. 2020a, Manca et al. 2020, Silva et al. 2020a). The lower total porosity values of SEB may have hindered the growth of the root system of seedlings under a low irrigation depth, making it difficult for water to go beyond the superficial region of the tube. Maximum growth is achieved when the allocation to photosynthetic tissues is maximized, although it must be considered that dry mass importance lies not only in the photosynthetic process but also in nutrient storage and during photosynthesis (Bravo Baeza et al. 2019, Kumarathunge et al. 2019).

Bueno et al. (2020) observed that increasing water supply can fail in improving seedlings development, which suggests the importance to know the requirements of the species during seedling production. If low water volumes are applied diregarding the proper maintenance of water in the container, stomata may close at higher temperatures, impairing photosynthesis and, consequently, plants growth and 
biomass accumulation (Taiz et al. 2014). Higher irrigations can increase nutrients leaching, and reduce water and nutrient use efficiency, as observed by Silva et al. (2020b) in tropical species.

Root system quality determines seedlings' ability to produce new roots quickly, defining the velocity with which they fix to the soil and grow soon after planting (Khanal et al. 2018). Root dry mass is related to higher survival and growth potential because they are required for the absorption and transport of water and nutrients from the soil to the shoot (Grossnickle \& MacDonald 2018). The appearance of particles that compose the substrates, such as size and shape, is one of the main factors that affect mixture arrangement and determines the space that the root system has to grow, especially in restricted volume containers (Fermino et al. 2018).

\section{Gas exchange}

Despite the practical importance of morphological measurements, physiological at tributes have a major influence on planting performance. Physiological processes are strongly influenced by environmental conditions, and understanding these processes is central to predict adaptive responses to field conditions, producing seedlings capable of establishing and growing in the field (Salmon et al. 2020). We observed that irrigation depths provided different plant responses in each substrate regarding gas exchange. Photosynthesis is a balance of light energy absorbed and consumed by plant's metabolic sinks and is therefore very sensitive to environmental changes (Zhang et al. 2020).

The higher assimilation rates $(A)$ allow species to maintain a competitive advantage over other plants at the post-establishment stage, as described by Le et al. (2019). Furthermore, the availability of water and air to the root system is very important for seedling growth, and substrates characteristics may provide these resources (Taiz et al. 2014). A reduction of $A$ in seedlings produced under 9 and $12 \mathrm{~mm}$ in SEB may be associated with the bigger size seedlings reached at the production cycle end, indicating the need for a larger container or immediate planting.

With lower irrigation depths, stomatal conductance $\left(g_{s}\right)$ and transpiration $(E)$ decreased. Bravo Baeza et al. (2019) obtained lower values of $g_{s}$ and $E$ in Cedrela odorata subjected to dry periods, which reflected in a higher WUE efficiency, as confirmed by our results. These authors also state that $g_{\text {s }}$ is an important predictor of water use and carbon assimilation, limiting plant growth, as observed in our results. Stomatal closure is a common response to water stress, as well as high vapor pressure deficit values (Taiz et al. 2014). It justifies the higher $E$ in plants with higher water availability detected in this study.

We observed that carbon assimilation $\left(C_{i}\right)$ values did not coincide with the alterations of $g_{s}$ and $E$. It indicates that, despite the stomatal opening, there was no increase in $\mathrm{CO}_{2}$ input in leaves, which can be explained by changes in the photosynthetic apparatus due to water or nutrient availability for plants (Baron et al. 2013). Photosynthesis is not only related to stomatal limitations but also nonstomatal limitations, such as the diffusion of $\mathrm{CO}_{2}$ from intercellular spaces to the chloroplasts and biochemical limitations to photosynthetic efficiency (Salmon et al. 2020). The availability of $C$ within the mesophyll cells is one of the factors that regulate the $C / C_{i}$ ratio, increasing or reducing its carboxylase activity and $A$ (Taiz et al. 2014).

Reflecting $A$ and $E$ values, water use efficiency (WUE) generally decreased as irrigation depths increased. We emphasize that not always the greatest WUE results in the greatest growth of seedlings, given that the assessment of gas exchange was carried out at the end of the production cycle. The increase in WUE is a preventive mechanism and immediate effect of water deficit related to $g_{s}$, as also reported in C. odorata subjected to dry periods (Bravo Baeza et al. 2019). Water availability and its use is an important factor determining growth and photosynthesis because it relates to temperature in leaves, which directly affects gas exchange (Kumarathunge et al. 2019). That is why this parameter is very important for defining irrigation management in nurseries, and it is clear from our results that an increased amount of water applied to seedlings does not always proportionally result in seedlings' growth and gas exchange.

\section{Conclusion}

In this study, we evaluated the use of sewage sludge-base substrates for seedlings production to increase the sustainability of seedling production process. Our results of morphological and physiological characteristics demonstrated that the substrates used in our study was able to provide conditions needed to produce highquality seedlings of Cedrela fissilis Vell. The daily irrigation depth must be adequate to species needs and substrates characteristics, increasing irrigation depth in substrates with reduced water holding capacity.

\section{Acknowledgements}

Funding was provided by CAPES - Coordination of Improvement of Higher Education Personnel, Brazil (financing code 001), FAPESP - São Paulo State Research Foundation, Brazil (process: 2013/50413-0), and the Ministère des Relations Internationales et de la Francophonie - Coopération QuébecBrésil from Québec (Canada) obtained by MMG.

\section{References}

Baron D, Ferreira G, Rodrigues JD, Boaro CSF, Macedo AC (2013). Gas exchange, phisiological indexes and ionic accumulation in Annona emarginata (Schltdl.) H. Rainer seedlings in nutrients solution. Revista Brasileira de Fruticultura 35: 361-376. - doi: 10.1590/s0100-2945201 3000200005

Barstow M (2018). Cedrela fissilis. The IUCN Red List of Threatened Species 2018: e.T33928A680 80477. - doi: 10.2305/IUCN.UK.2018-1.RLTS.T339 28A68080477.en

Bortolini J, Tessaro D, Gonçalves MS, Oro SR (2017). Sewage sludge and broiler litter component of substrates for seedling production Cedrela fissilis e Anadenanthera macrocarpa (Benth). Brenan. Scientia Agraria 18: 121-128. doi: $10.5380 /$ rsa.v18i4.53698

Braga NCC, Severiano EC, Santos LS, Neto AR, Rodrigues TM, Lima JDP (2019). Production of sugarcane seedlings pre-sprouted in commercial and alternative substrates with by-products of the sugarcane industry. Ciências Agrárias 40: 33-48. - doi: 10.5433/1679-0359.2019v40n1p33 Bravo Baeza NI, Osorio Vélez LF, Bravo Oviedo F, Martínez Bustamante E (2019). Survival, growth and photosynthesis analysis of native forest species established in the tropical dry forest in Antioquia, Colombia. Revista Facultad Nacional de Agronomia Medellin 72: 8751-8761. - doi: 10.15446/rfnam.v72n1.69575

Bueno MM, Leles PSS, Abreu JFG, Santos JJS, Carvalho DF (2020). Water requirement and growth indicators of forest tree species seedlings produced with automated irrigation management. PLoS One 15 (11): e0238677. - doi: 10.1371/journal.pone.0238677

Chemetova C, Fabião A, Gominho J, Ribeiro H (2018). Range analysis of Eucalyptus globulus bark low-temperature hydrothermal treatment to produce a new component for growing media industry. Waste Management 79: 1-7. - doi: 10.1016/j.wasman.2018.07.019

De Abreu AHM, Marzola LB, De Melo LA, Leles PSS, Abel ELS, Alonso JM (2017). Urban solid waste in the production of Lafoensia pacari seedlings. Revista Brasileira de Engenharia Agrícola e Ambiental 21: 83-87. - doi: 10.1590/18071929/agriambi.v21n2p83-87

Dumroese K, Landis T, Pinto J, Haase D, Wilkinson K, Davis A (2016). Meeting forest restoration challenges: using the target plant concept. Reforesta 1 (1): 37-52. - doi: 10.21750/refor.1.03.3 Fermino MH, Araujo MM, Aimi SC, Turchetto F, Berghetti ALP, Zavistanovicz TC, Mieth P, Griebeler AM, Vilella JM (2018). Reutilization of residues as components of substrate for the production of Eucalyptus grandis seedlings. Cerne 24: 80-89. - doi: 10.1590/01047760201824022522 Fornes F, Belda RM (2019). Use of raw and acidified biochars as constituents of growth media for forest seedling production. New Forests 50: 1063-1086. - doi: 10.1007/s11056-019-09715-y Gabira MM, Silva RBG, Mateus CMD, Villas Bôas RL, Silva MR (2020a). Effects of water management and composted sewage sludge substrates on the growth and quality of clonal eucalyptus seedlings. Floresta 50: 1307-1314. - doi: 10.5380/rf.v50i2.62952

Gabira MM, Walter LS, Brito GS, Schneider CR, Wendling I, Kratz D (2020b). Alternative substrates and containers for llex paraguariensis seedlings production. Acta Iguazu 9: 78-87. doi: 10.48075/actaiguaz.vgi4.25492

Georgin J, Franco DSP, Grassi P, Tonato D, Piccilli 
DGA, Meili L, Dotto GL (2019). Potential of Cedrella fissilis bark as an adsorbent for the removal of red 97 dye from aqueous effluents. Environmental Science and Pollution Research 26: 19207-19219. - doi: 10.1007/s11356-019-053219

Girona MM, Lussier JM, Morin H, Thiffault N (2018). Conifer regeneration after experimental shelterwood and seed-tree treatments in boreal forests: finding silvicultural alternatives. Frontiers in Plant Science 9: 1145. - doi: 10.3389/ fpls.2018.01145

Grossnickle SC, MacDonald JE (2018). Why seedlings grow: influence of plant attributes. New Forests 49: 1-34. - doi: 10.1007/s11056-017-96064

Guerrini IA, Trigueiro RM (2004). Atributos físicos e químicos de substratos compostos por biossólidos e casca de arroz carbonizada [Physical and chemical attributes of substrates composed of biosolids and carbonized rice chaff]. Revista Brasileira de Ciência do Solo 28: 10691076. [in Portuguese with English summary] doi: $10.1590 /$ S0100-06832004000600016

Hu B, Chu C (2020). Nitrogen - phosphorus interplay: old story with molecular tale. New Phytologist 225: 1455-1460. - doi: 10.1111/nph.16102

IBA (2019). Relatório IBÁ 2019. Indústria Brasileira de Árvores - IBA, São Paulo, Brazil, pp. 80. [in Portuguese] [online] URL: http://iba.org/da tafiles/publicacoes/relatorios/iba-relatorioanual 2019.pdf

Ivetić V, Devetaković J, Maksimović Z (2016). Initial height and diameter are equally related to survival and growth of hardwood seedlings in first year after field planting. Reforesta 2: 6-21. doi: 10.21750/refor.2.02.17

Khanal PN, Dean TJ, Roberts SD, Grebner DL, Straka TJ (2018). Explaining first-year seedling survival from quality distributions of bare-root seedlings and microsites in industrial plantations. Open Journal of Forestry 8: 362-379. doi: 10.4236/ojf.2018.83023

Kormanek M, Malek S, Banach J, Durlo G, Jagiello-Lenczuk K, Dudek K (2020). Seasonal changes of perlite-peat substrate properties in seedlings grown in different sized container trays. New Forests 52 (2): 271-283. - doi: $10.1007 /$ s11056-020-09793-3

Kratz D, Nogueira AC, Wendling I, Elias JEM (2017). Physic-chemical properties and substrate formulation for Eucalyptus seedlings production. Scientia Forestalis 45: 63-76. - doi: 10.18671/scifor.v45n113.06

Kumarathunge DP, Drake JE, Tjoelker MG, López R, Pfautsch S, Vårhammar A, Medlyn BE (2019). The temperature optima for tree seedling photosynthesis and growth depend on water inputs. Global Change Biology 26 (4): 2544-2560. - doi: 10.1111/gcb.14975

Le Q, Tennakoon KU, Metali F, Sukri RS (2019). Photosynthesis in co-occurring invasive Acacia spp. and native Bornean heath forest trees at the post-establishment invasion stage. Journal of Sustainable Forestry 38: 230-243. - doi: 10.108 o/10549811.2018.1530602

Lopes MC, Mateus CMD, Alves DAS, Tavares AR, Sanches LVC, Villas Bôas RL (2018). Sewage sludge compost as a substrate for croton seedlings production. Ornamental Horticulture 24: 380-386. - doi: 10.14295/oh.v24i4.1234

Madrid-Aispuro RE, Prieto-Ruíz JA, Aldrete A, Hernández-Díaz JC, Wehenkel C, Chávez-Simental JA, Mexal JG (2020). Alternative substrates and fertilization doses in the production of $\mathrm{Pi}$ nus cembroides Zucc. in nursery. Forests 11 (1): 71. - doi: 10.3390/f11010071

Manca A, Silva MR, Guerrini IA, Fernandes DM, Villas Bôas RL, Silva LC, Fonseca AC, Ruggiu MC, Cruz CV, Sivisaca DCL, Mateus CMD, Murgia I, Grilli E, Ganga A, Capra GF (2020). Composted sewage sludge with sugarcane bagasse as a commercial substrate for Eucalyptus urograndis seedling production. Journal of Cleaner Production 269 (Suppl. 1): 122145. - doi: 10.1016/j.jcle pro.2020.122145

Nascimento AL, Souza AJ, Oliveira FC, Coscione AR, Viana DG, Regitano JB (2020). Chemical attributes of sewage sludges: Relationships to sources and treatments, and implications for sludge usage in agriculture. Journal of Cleaner Production 258: 120746. - doi: 10.1016/j.jclepro. 2020.120746

Navroski MC, Tonett EL, Mazzo MV, Frigotto T, Pereira MDO, Galvani LV (2016). Procedência e adubação no crescimento inicial de mudas de cedro [Provenances and fertilizer on early growth cedar seedlings]. Pesquisa Florestal Brasileira 36: 17-24. [in Portuguese] - doi: 10.433 6/2016.pfb.36.85.966

Pascual JA, Ceglie F, Tuzel Y, Koller M, Koren A, Hitchings $R$, Tittarelli $F$ (2018). Organic substrate for transplant production in organic nurseries. A review. Agronomy for Sustainable Development 38 (3): 197. - doi: 10.1007/s13593018-0508-4

R Core Team (2020). R: a language and environment for statistical computing. R Foundation for Statistical Computing, Vienna, Austria. [online] URL: http://www.r-project.org/

Raviv M (2013). Composts in growing media: what's new and what's next? Acta Horticulturae 982: 39-52. - doi: 10.17660/ActaHortic.20 13.982 .3

Sá FP, Belniaki AC, Panobianco M, Gabira MM, Kratz D, Lima EA, Wendling I, Magalhães WLE (2020). Peach palm residue compost as substrate for Bactris gasipaes self-sustaining seed- lings production. International Journal of Recycling of Organic Waste in Agriculture 9: 183-191. - doi: 10.30486/IJROWA.2020.1891396.1030 Sahu O (2018). Assessment of sugarcane industry: suitability for production, consumption, and utilization. Annals of Agrarian Science 16: 389-395. - doi: 10.1016/j.aasci.2018.08.001

Salmon Y, Lintunen A, Dayet A, Chan T, Dewar R, Vesala T, Hölttä T (2020). Leaf carbon and water status control stomatal and nonstomatal limitations of photosynthesis in trees. New Phytologist 226 (3): 690-703. - doi: 10.1111/nph.164 36

Salvador SM, Schumacher MV, Viera M, Stahl J, Consensa CB (2016). Biomassa e estoque de nutrientes em plantios clonais de Eucalyptus saligna Smith. em diferentes idades [Biomass and nutrient stocks in clonal plantations of Eucalyptus saligna Smith. at different ages]. Scientia Forestalis 44: 311-321. [in Portuguese with English summary] - doi: 10.18671/scifor.v44n110. 04

Silva LOC, Fonseca AC, Sivisaca DCL, Silva MR, Boas RLV, Guerrini IA (2020a). Sewage sludge compost associated to frequency of irrigation for Peltophorum dubium (Sprengel) Taubert seedlings production. Floresta 50: 1389-1398. doi: 10.5380/rf.v50i2.64158

Silva RBG, Gabira MM, Prado DZ, Uesugi G, Simões D, Silva MR (2020b). Influence of mean leaf angles and irrigation volumes on water capture, leaching, and growth of tropical tree seedlings. Forests 11 (11): 1198. - doi: 10.3390/f111 11198

Silva RBG, Silva MR (2015). Effects of water management on growth, irrigation efficiency and initial development of Aspidosperma polyneuron seedlings. African Journal of Agricultural Research 10: 3562-3569. - doi: 10.5897/AJAR20 15.10088

Sonneveld C (1988). Analytical methods for substrates in the Netherlands. Acta Horticulturae 221: 413-416. - doi: 10.1766o/actahortic.1988.221. 47

Stuepp CA, Kratz D, Gabira MM, Wendling I (2020). Survival and initial growth in the field of eucalyptus seedlings produced in different substrates. Pesquisa Agropecuária Brasileira. 55: e01587. - doi: 10.1590/s1678-3921.pab2020.v55.0 1587

Taiz L, Zeiger E, Mller IM, Murphy A (2014). Plant physiology and development ( $6^{\text {th }}$ edn). Sinauer Associates, Sunderland, MS, USA, pp. 761.

Zhang C, Yi X, Gao X, Wang M, Shao C, Lv Z, Chen J, Liu Z, Shen C (2020). Physiological and biochemical responses of tea seedlings (Camellia sinensis) to simulated acid rain conditions. Ecotoxicology and Environmental Safety 192: 110315. - doi: 10.1016/j.ecoenv.2020.110315 